\title{
CLINICO-MORPHOLOGICAL PROFILE IN BREAST CANCER PATIENTS IN A TERTIARY CARE HOSPITAL IN WESTERN RAJASTHAN
}

\author{
Meenakshi Rao' ${ }^{1}$ Rajni Joshee ${ }^{2}$, Meeta Deval ${ }^{3}$, Neha Sethi ${ }^{4}$ \\ ${ }^{1}$ Senior Resident, Department of Pathology, Dr. S. N. Medical College, Jodhpur, Rajasthan, India. \\ 2 Professor, Department of Pathology, Dr. S. N. Medical College, Jodhpur, Rajasthan, India. \\ ${ }_{3}^{3}$ Associate Professor, Department of Pathology, Dr. S. N. Medical College, Jodhpur, Rajasthan, India. \\ ${ }^{4}$ Consultant, Department of Pathology, Eternal Hospital, Jaipur, Rajasthan, India.
}

\section{ABSTRACT}

\section{BACKGROUND}

Breast cancer is the most common malignancy in females. Data on breast cancer profile of patients in Rajasthan, especially Western region is scant. The clinical and morphological presentation may be different due to which appropriate strategy may have to be employed for screening, diagnosis and treatment purpose.

AIMS

To study the clinical and morphological profile in breast carcinoma patients in a tertiary care hospital in Western Rajasthan.

\section{METHODS}

This prospective study was carried out on 50 newly diagnosed cases of breast carcinoma. The cases were confirmed on cytology following which the morphology was examined on biopsies.

\section{STATISTICAL ANALYSIS}

Data was analysed by using Statistical Package for Social Sciences (SPSS) version 21 where required.

\section{RESULTS}

Mean age of patients was found to be lower compared to western countries. Many of the patients were from rural background and patients often presented with longer duration of symptoms and advanced clinical stage. Left side was more frequently involved. The tumour was commonly of higher grade (Grade 3).

\section{CONCLUSION}

Breast cancer occurs in younger age females in India including Western Rajasthan region. Considering the younger age of presentation of patients and decreased affordability of patients, mammography might be a less effective screening test due to higher density of breast in young age, which decreases the sensitivity of mammography. Patients are mostly from rural background and present more frequently with advanced stage breast cancer. The cancer is frequently high grade and increased involvement of lymph nodes is also seen. Awareness campaigns, breast self-examination, improved access to diagnostic resources and health care are important measures that should be unde rtaken for increasing early diagnosis. To the best of our knowledge, this is the first study examining the clinico-morphological profile of breast cancer patients in Western Rajasthan region.

\section{KEYWORDS}

Breast Cancer-Clinical Profile-Stage-Grade-India.

HOW TO CITE THIS ARTICLE: Rao M, Joshee R, Deval M, et al. Clinico-morphological profile in breast cancer patients in a tertiary care hospital in Western Rajasthan. J Evolution Med Dent Sci 2016;5(4):262-265, DOI: 10.14260/jemds/2016/55

\section{INTRODUCTION}

Breast cancer is the most common cancer in women with an estimated 1.38 million new cases in a year $(23 \%$ of all cancers). ${ }^{1}$ It accounts for $15 \%$ of cancer mortalities in females. $^{2}$ The cases of breast cancer have been increasing over the world in the last few decades. ${ }^{3,4}$ and the increase has been especially great in developing Asian countries. ${ }^{5}$ India reports roughly 1,00,000 new cases annually. ${ }^{6}$ However, these figures are from the National Cancer Registry and the Hospital based Tumour Registry and they do not adequately sample the total population.

Financial or Other, Competing Interest: None.

Submission 12-12-2015, Peer Review 13-12-2015,

Acceptance 09-01-2016, Published 14-01-2016.

Corresponding Author:

Meenakshi Rao

Department of Pathology,

Dr. S. N. Medical College \& Hospital,

Jodhpur,

Rajasthan, India.

E-mail: drmeenakshirao@gmail.com

DOI:10.14260/jemds/2016/55
The classification and prognosis of breast cancer is based on a large part on histopathological parameters such as tumour size, type, grade and lymph node status. ${ }^{7-15}$ However, only few studies from India are present. ${ }^{16-19}$ and to the best of our knowledge, no study from Western Rajasthan regarding the clinico-histological parameters of breast cancer is available.

\section{MATERIALS AND METHODS}

The study was conducted at Dr. S. N. Medical College and associated hospitals by the Department of Pathology; 50 new cases of breast cancer which were proven on cytology from October 2012 to August 2013 were included in the study. Detailed clinical history relating to age, symptoms, duration of symptoms, menopausal status, family history was taken. All the patients were thoroughly examined and clinically staged according to the TNM classification of carcinomas of the breast. ${ }^{20}$ Few of the patients had sonography of abdomen and liver function tests done. 
After cytological confirmation, the lump was biopsied and processed and the histopathology was examined. The following pathological features were assessed on the biopsiestumor type, histological grade, presence or absence of coexistent in situ component. The tumours were typed in accordance with the WHO.21 They were graded according to the Nottingham modification of the Bloom and Richardson method.15 Additional histological prognostic informationlymphovascular invasion and presence and extent of tumor necrosis was also looked for. The data was tabulated in Microsoft Excel 2013 and analysed by using Statistical Package for Social Sciences (SPSS) version 21 where required.

\section{RESULTS}

A total of 50 new cases of breast cancer from October 2012 to August 2013 were studied. A majority of the patients were in the age group 40-50 years (Table 1). The youngest patient was 27 years and the oldest patient was 78 years old and the mean age of patients was 48.6 years. All the patients in the study were females; $58 \%$ of the patients were postmenopausal (Table 2). A total of $33(66 \%)$ patients were from rural background and 17 (34\%) were from urban background with the ratio of 1.9:1.

None of the patients had a family history of breast cancer. Two patients $(4 \%)$ were nulliparous. All the other patients were multiparous and had history of breast feeding. The most common symptom was breast lump, present in all the cases. The lump was seen to be slightly more common on the left side; 27 (54\%) patients had a left breast lump and 23 (46\%) patients had a right breast lump. Majority of the patients had lump in the upper outer quadrant. None of the patients had bilateral breast lumps. One patient had history of nipple discharge and 8 patients (16\%) also had history of associated pain in the lump (Table 3). The duration of the symptoms ranged from 20 days to 4 months; 21 (42\%) patients had symptoms for more than 2 months.

Tumour size taken as the maximum diameter on clinical examination, ranged from $1.5 \mathrm{cms}$ to $9.5 \mathrm{cms}$ in maximum dimension. Maximum number of patients had tumour size in the range of 2 to $5 \mathrm{cms}$ (Table 4). Lymphadenopathy was present in $24(48 \%)$ of the cases. All these patients had ipsilateral axillary lymphadenopathy. Clinical TNM staging done of the patients is shown in Table (Table 5). Liver function tests, chest X-ray and ultrasonography of abdomen were done to exclude metastasis. Mammography was done in only few patients. Liver function tests were not altered in any of the patients.

Histological typing of the tumour was done on biopsies (Incision biopsies) subsequently. All the cases were Invasive Ductal Carcinoma, NOS except one case of mucinous carcinoma. Histological grading done by Nottingham modification of the Bloom and Richardson method showed maximum tumours of grade 3 (42\%- Figures 1 - 3), 34\% of the tumours were grade 2 and $24 \%$ were grade 1 (Table 5). Additionally, tumour necrosis was seen in $6 \%$ of the biopsies and lymphovascular invasion was seen in $4 \%$ of the biopsies.

\section{DISCUSSION}

Breast cancer is the most common non-skin malignancy in women.22 According to the National and Regional cancer registries, it is the commonest cancer in women in Delhi, Mumbai, Ahmedabad, Kolkata and Trivandrum and the second most common site among women. The age standardized rates range from 9-28.6 per 100,000 women. ${ }^{23}$

The aim of this study was to examine the clinicopathological profile of breast cancer patients in Western Rajasthan as such studies are sparse. The majority of patients were seen in the fourth to sixth decade of life. Similar figures have been reported from India and other Asian countries. ${ }^{24-26}$ as well as Rajasthan. ${ }^{27}$ However, female breast carcinoma is predominantly seen in the fifth decade onward in Western countries. ${ }^{28,29}$ Of all the patients, $66 \%$ of the patients were from rural background. This difference was statistically significant. Similar finding was seen in only one other Indian study. ${ }^{17}$ However, other studies in India as well as from the United States show higher incidence in urban population. ${ }^{24,30}$ This difference could be due to the fact that our hospital has a large rural periphery and therefore caters to mostly rural population.

Also, women from rural areas often have difficulty in accessing health care services and a large proportion of India's population is from rural areas. All the patients presented with lump in the breast. Few of the patients had associated pain as well. A single patient also had nipple discharge. The lump in breast was more common on the left side and that too in the upper outer quadrant. This is possibly due to bulkier left breast and more breast tissue in the upper outer quadrant. Similar findings have been seen in other studies. ${ }^{27,31,32,33}$ Only $4 \%$ of patients were nulliparous. This figure is lower than seen in other studies. ${ }^{17,34,35}$ The reason for this is not clear and a larger study is needed to confirm this finding.

Only a single patient (2\%) presented in stage I. Majority of the patients presented at stage II or more. This could again be delayed access to health care services. Only $27 \%$ of patients with tumours belonging to stage $\mathrm{T} 2$ or less had lymph node metastasis. In contrast, $76 \%$ of patients with clinical stage T3 or more had lymph node metastasis. This direct relationship between tumour size and lymph node status has been established. ${ }^{36}$

Additional investigations done were liver function tests, sonography abdomen and chest X-ray. Chest X-ray and ultrasonography picked up cases of metastasis. However, liver function tests were normal in all the cases, which raises questions regarding the sensitivity of this investigation for metastatic workup. Mammography and bone scan were not routinely done in patients due to decreased availability and economic issues for many patients. Moreover, mammography is largely useful for detecting early stage breast cancer. In our study, patients presented with advanced stage breast cancer. Literature also shows that complete metastatic workup is not necessary in many newly diagnosed breast cancer patients, and may be done for some patients only, such as stage III or advanced disease. 37

On histological typing, $98 \%$ of the cases were Invasive Ductal Carcinoma, NOS. and 2\% mucinous carcinoma (Colloid carcinoma). It has been seen that Invasive Ductal Carcinoma, NOS accounts for $47-75 \%$ of cases of breast carcinoma and mucinous carcinoma for $1-4 \%$ of cases. ${ }^{10}$ Other Indian studies have also shown Invasive Ductal Carcinoma, NOS to be the commonest tumour. ${ }^{38,39}$ On histopathological grading, maximum number of patients had grade 3 tumour (42\%), 34\% had grade 2 tumour and $24 \%$ had grade 1 tumour. Other studies have also shown similar results. 38,40 Tumour necrosis was seen in $6 \%$ of the biopsies and lymphovascular invasion 
was seen in $4 \%$ of the biopsies. However, these figures is higher in literature. 40,41

This discrepancy could be due to the smaller size of preoperative biopsies in the current study compared to modified radical mastectomies in the other studies. In conclusion, compared to developed countries, breast cancer occurs in younger age females in India. However, considering the younger age of presentation of patients and decreased affordability of patients, mammography might be a less effective screening test due to higher density of breast in young age, which decreases the sensitivity of mammography. Patients present more frequently with advanced stage breast cancer. The cancer is frequently high grade and increased involvement of lymph nodes is also seen. Awareness campaigns, breast self-examination, improved access to diagnostic resources and health care are important measures that should be undertaken for increasing early diagnosis.

\section{REFERENCES}

1. Jacques Ferlay, Hai-Rim Shin, Freddie Bray, et al. Estimates of worldwide burden of cancer in 2008. GLOBOCAN 2008. Int J Cancer 2010;127:2893-2917.

2. Kumar V, Abbas AK, Aster J. The Breast. In: Robbins and Cotran Pathologic Basis of Disease. 9th Ed. Philadelphia, WB Saunders, 2015:276.

3. Peggy Porter. "Westernizing" women's risk? Breast cancer in lower income countries. N Engl J Med 2008;358:213-216.

4. Andersen BO, Jakesz R. Breast cancer issues in developing countries: an overview of the Breast Health Global Initiative. World J Surg 2008;32(12):2578-85.

5. Green M, Raina V. Epidemiology, screening and diagnosis of breast cancer in the Asia-Pacific region: Current perspectives and important considerations. Asia-Pacific J of Clin Oncology 2008;4:S5-S13.

6. Bagchi S. Breast cancer rises in India. CMAJ 2008 July;179(1):27.

7. Fisher ER, Sass R, Fisher B, et al. Pathologic findings from the National Surgical Adjuvant Breast Project for breast cancer (Protocol No. 4): discrimination for tenth year treatment failure. Cancer 1984;53:712-723.

8. Carter CL, Allen C, Henson DE. Relation of tumor size, lymph node status and survival in 24,740 breast cancer cases. Cancer 1989;63:181-187.

9. Russo J, Frederick J, Ownby HE, et al. Predictors of recurrence and survival of patients with breast cancer. Am J Clin Pathol 1987;88:123-131.

10. Fletcher DM. Tumors of the breast. In: Diagnostic histopathology of tumors; Elsevier, third edition, 2007:942.

11. Rosen PP, Harris JR, Hellman S, et al. Breast disease. Philadelphia JB Lippincott, 1987;181-185.

12. Greenough RB. Varying degrees of malignancy in cancer of the Breast. J Cancer Res 1925;9:452-463.

13. Bloom JHG, Richardson WW. Histologic grading and prognosis in Breast Cancer. Br J Cancer 1957;9:359-377.

14. Henson DE, Ries L, Freedman LS, et al. Relationship among outcome, stage of disease and histologic grade for 22,616 cases of breast cancer. Cancer 1991;68:21422149 .
15. Elston CW, Ellis IO, et al. Pathological prognostic factors in breast cancer. The role of histological grade in breast cancer: experience from a large study with long-term followup. Histopathology 1991;19:403-410.

16. Kulkarni BB, Hiremath SV, Kulkarni SS, et al. Decade of breast cancer care center in South India. Asian Journal of epidemiology. 2012;5(4):103-113.

17. Sandhu DS, Sandhu S, Karwasra RK, et al. Profile of breast cancer patients at a tertiary care hospital in North India. Indian J Cancer 2010;47:16-22.

18. Harrison PA, Srinivasan K, Binu VS, et al. Risk factors for breast cancer among women attending a tertiary care hospital in Southern India. International J Collaborative Research on Internal Medicine and Public Health 2010;2:109-116.

19. Raina V, Bhutani M, Bedi R, et al. Clinical features and prognostic factors of early breast cancer at a major cancer center in North India. Indian J Cancer 2005;42:3641.

20. Edge SB, Byrd DR, Fritz AG, et al., editors. AJCC cancer staging manual ( $7^{\text {th }}$ ed). New York, NY: Springer; 2010.

21. Tavassoli FA, Devilee P (Eds). World Health Organization classification of tumours. Pathology and Genetics of Tumours of the Breast and Female Genital Organs. IARC Press: Lyon, 2003.

22. Kumar V, Abbas AK, Aster J. The Breast. In: Robbins and Cotran Pathologic Basis of Disease. 9th 5d. Philadelphia, WB Saunders, 2010:1051.

23. National Cancer Registry Programme. Consolidated report of population based cancer registries. ICMR, 2001-2004.

24. Chopra R. The Indian scene. Journal of Clinical Oncology 2001;19:S106-11.

25. Chow LW, Ting AC, Cheung KL, et al. Current status of breast cancer in Hong Kong. Chin Med J (Engl) 1997;110:474-8.

26. Malik IA. Clinico-pathological features of breast cancer in Pakistan. J Pak Med Assoc 2002;52:100-4.

27. Gupta P, Sharma RG, Verma M. Review of breast cancer cases in Jaipur region. J Indian Med Assoc 2002;100:282-3, 286-7.

28. El-Tamer MB, Wait RB. Age of presentation of AfricanAmerican and Caucasian breast cancer patients. J Am Coll Surg 1999;188:237-40.

29. Hospital Episode Statistics Vol. 2 1991/92. Department of Health. London: HMSO, 1995.

30. Coughlin SS, Thompson TD, Hall HI, et al. Breast and cervical carcinoma screening practices among women in rural and non-rural areas of the United States. 19981999. Cancer 2002;94:2801-12.

31. Staszewski J. Age at menarche and breast cancer. J Natl Cancer Inst 1971;47:935.

32. McPherson K, Steel CM, Dixon JM. ABC of breast diseases. Breast cancer-epidemiology, risk factors, genetics. BMJ 2000;321:624-8.

33. Lee $\mathrm{AH}$. Why is carcinoma of the breast more frequent in the upper outer quadrant? A case series based on needle core biopsy diagnoses. Breast 2005;14:151-2.

34. Kelsey JL, Gammon MD, John EM. Reproductive factors and breast cancer. Epidemiol Review 1993;15:36. 
35. Rosner B, Colditz GA, Willett WC. Reproductive risk factors in a prospective study of breast cancer: the nurses' health study. Am J Epidemiol 1994;139:819.

36. Palmer MK, Lythgoe JP, Smith A, et al. Prognostic factors in breast cancer. Br J of Surgery 1982;69:697-698.

37. Puglisi F, Follador A, Minisini AM, et al. Baseline staging tests after a new diagnosis of breast cancer: further evidence of their limited indications. Ann Oncol 2005;16:263-6.

38. Shet T, Agrawal A, Nadkarni M, et al. Hormone receptors over the last eight years in a cancer referral center in India: What was and what is? Indian J Pathol Microbiol 2009;52:171-4.

39. Sofi GN, Sofi JN, Nadeem R, et al. Estrogen receptor and progesterone receptor status in breast cancer in relation to age, histological grade, size of lesion and lymph node involvement. Asian Pac J Cancer Prev 2012;13:5047-52.

40. Ghosh S, Sarkar S, Simhareddy S, et al. Clinicomorphological profile and receptor status in breast cancer patients in a South Indian Institution. Asian Pac J Cancer Prev 2014;15(18):7839-7842.

41. Rao C, Shetty J, Kishan Prasad HL. Morphological profile and receptor status in breast carcinoma: an institutional study. J Cancer Res Ther 2013;9:44-49.

\begin{tabular}{|c|c|c|}
\hline Age Interval & $\begin{array}{c}\text { No. of } \\
\text { Patients }\end{array}$ & $\begin{array}{c}\text { Percentage } \\
(\%)\end{array}$ \\
\hline $30-40$ & 7 & 14 \\
\hline $40-50$ & 17 & 34 \\
\hline $50-60$ & 12 & 24 \\
\hline $60-70$ & 6 & 12 \\
\hline $70-80$ & 8 & 16 \\
\hline T0TAL & $\mathbf{5 0}$ & $\mathbf{1 0 0}$ \\
\hline \multicolumn{2}{|c|}{ Table 1: Age distribution of Patients } \\
\hline
\end{tabular}

\begin{tabular}{|c|c|c|}
\hline $\begin{array}{c}\text { Menstrual } \\
\text { Status }\end{array}$ & $\begin{array}{c}\text { No. of } \\
\text { Patients }\end{array}$ & $\begin{array}{c}\text { Percentage } \\
(\%)\end{array}$ \\
\hline Pre-Menopausal & 21 & 42 \\
\hline Post-Menopausal & 29 & 58 \\
\hline TOTAL & $\mathbf{5 0}$ & $\mathbf{1 0 0}$ \\
\hline \multicolumn{2}{|c|}{ Table 2: Menopausal Status } \\
\hline
\end{tabular}

\begin{tabular}{|c|c|c|}
\hline Symptoms & Present & $\begin{array}{c}\text { Percentage } \\
(\%)\end{array}$ \\
\hline Breast Lump & 50 & 100 \\
\hline Pain & 08 & 16 \\
\hline Discharge from Nipple & 1 & 2 \\
\hline \multicolumn{2}{|c|}{ Table 3: Clinical Presentations } \\
\hline
\end{tabular}

\begin{tabular}{|c|c|c|}
\hline Tumour Size (Cms) & $\begin{array}{c}\text { No. of } \\
\text { Patients }\end{array}$ & $\begin{array}{c}\text { Percentage } \\
\text { (\%) }\end{array}$ \\
\hline$<2$ & 1 & 2 \\
\hline $2-5$ & 28 & 56 \\
\hline$>5$ & 21 & 42 \\
\hline TOTAL & $\mathbf{5 0}$ & $\mathbf{1 0 0}$ \\
\hline \multicolumn{2}{|c|}{ Table 4: Tumour Size } \\
\hline
\end{tabular}

\begin{tabular}{|c|c|c|}
\hline TNM Staging & $\begin{array}{c}\text { No. of } \\
\text { Patients }\end{array}$ & $\begin{array}{c}\text { Percentage } \\
\text { (\%) }\end{array}$ \\
\hline T1N0M0 & 1 & 2 \\
\hline T2N0M0 & 20 & 40 \\
\hline T2N1M0 & 8 & 16 \\
\hline T3N0M0 & 4 & 8 \\
\hline T3N1M0 & 7 & 14 \\
\hline T4bN0M0 & 1 & 2 \\
\hline T4bN1M0 & 8 & 16 \\
\hline T4bN1MX & 1 & 2 \\
\hline TOTAL & $\mathbf{5 0}$ & $\mathbf{1 0 0}$ \\
\hline \multicolumn{2}{|c|}{ Table 5: Clinical TNM Staging } \\
\hline
\end{tabular}

\begin{tabular}{|c|c|c|}
\hline BR Score & $\begin{array}{c}\text { No. of } \\
\text { Patients }\end{array}$ & $\begin{array}{c}\text { Percentage } \\
\text { (\%) }\end{array}$ \\
\hline BRS 4 & 2 & 4 \\
\hline BRS 5 & 10 & 20 \\
\hline BRS 6 & 12 & 24 \\
\hline BRS 7 & 5 & 10 \\
\hline BRS 8 & 12 & 24 \\
\hline BRS 9 & 9 & 18 \\
\hline TOTAL & $\mathbf{5 0}$ & $\mathbf{1 0 0}$ \\
\hline \multicolumn{3}{|c|}{ Table 6: Bloom Richardson Score (BRS) } \\
\hline
\end{tabular}

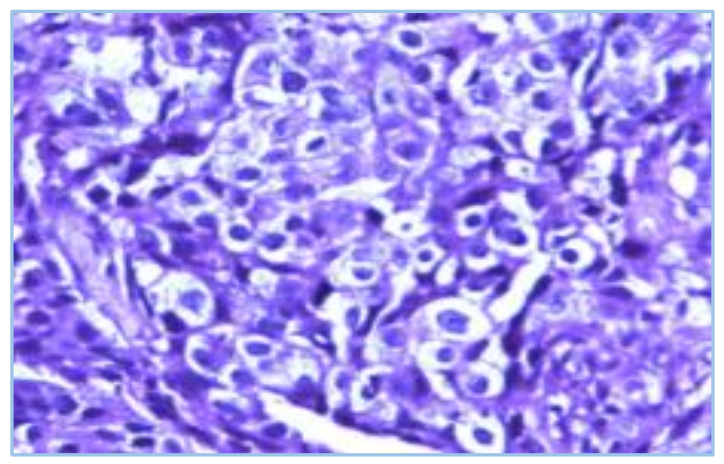

Fig. 1: High grade Invasive Ductal Carcinoma, NOS (40x)

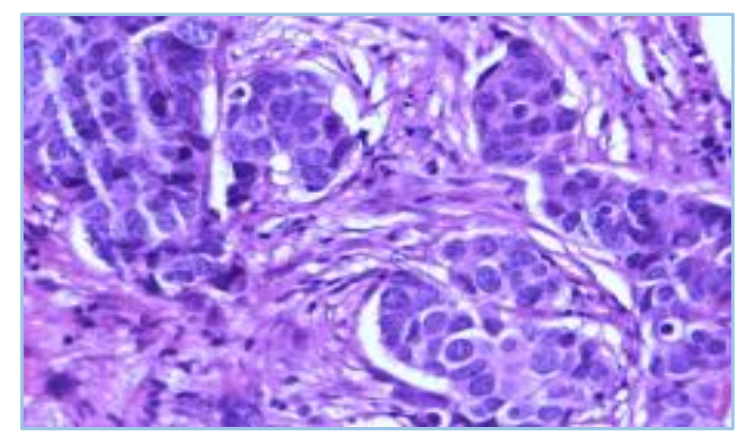

Fig. 2: High grade Invasive Ductal Carcinoma, NOS (40x)

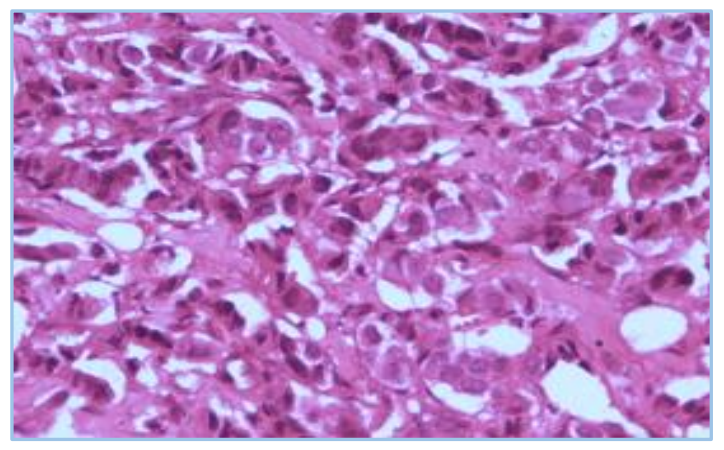

Fig. 3: High grade Invasive Ductal Carcinoma, NOS (40x) 